\title{
Observe a strange event: Timon of Athens, Seattle
}

by Sean Henry. Published in 2018 Issue 1.

For the production: Timon of Athens (2018, Seattle Shakespeare Company). Date performance attended: 2018-0203. See production details at the end of the review.

The Seattle Shakespeare Company's PRoduction of Timon of ATHENS WAS ONE Of PROfESSiONAL and private firsts: the first time staging the play in the twenty-seven-year history of the company, and the first time this reviewer saw the play staged live. I mentioned my going to the play to a number of academic colleagues worldwide (thanks to social media), and I was surprised by how many of them admitted they'd never seen the play performed. Seeing the play is a rarity, as is staging it. I spoke briefly with the company's managing director, who said that Timon was one of the few remaining Shakespeare plays they hadn't staged, so their choice was partly based upon a desire to complete the canon, though he admitted they were taking a risk in playing it. Unloved and unlovely, and quite possibly a collaboration with Middleton, the play has a comparatively simple plot, but crackles with Timon's hatred for humanity.

In director John Kazanjian's hands, the play comments on the transactional nature of human relationships. Mary Ewald as Timon appears before the play to deliver a non-Shakespearean prologue on power, typifying it very much like fortune. Power is fleeting, power watches, and power laughs, even "as you are dying in a private clinic." In a week full of news about Amazon's proposal to create a healthcare system for its employees, with parallel Amazon hospitals superseding those available to the public, it was hard not to see this production as a comment on the wealth inequalities coming increasingly to the fore in American society (Seattle is an Amazon town, after all). Ewald as Timon embraces this note about health: she begins the play in health when Timon has money, giving the character a physical litheness that disappears into a crabbed crouch as disappointment drives

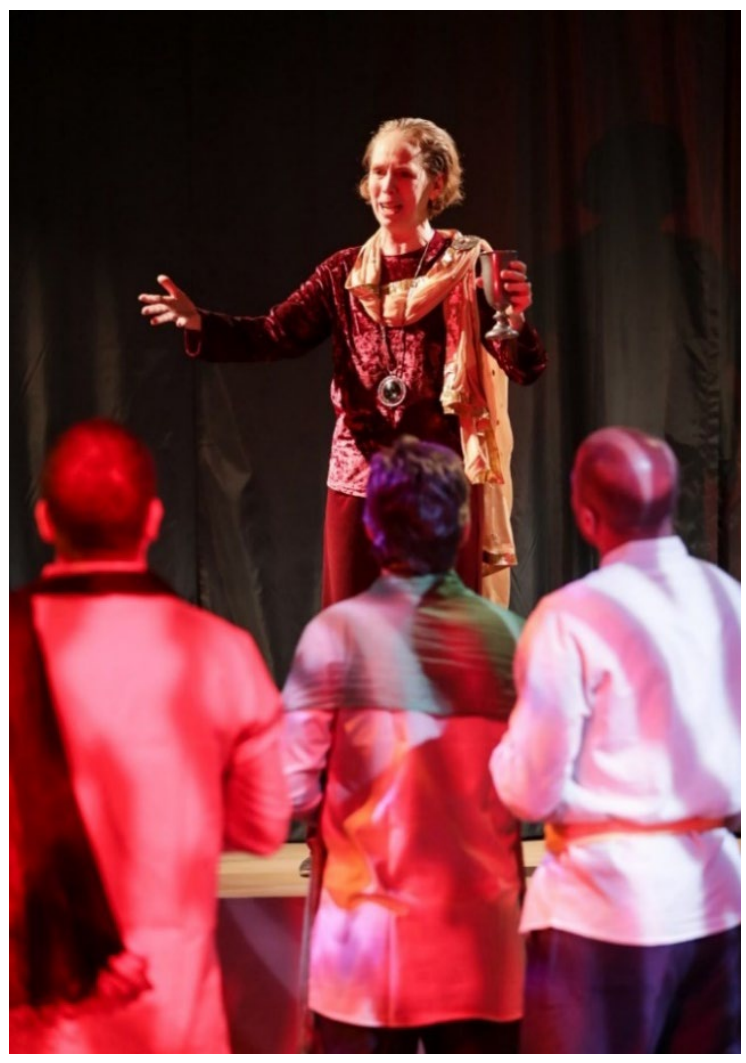

Figure 1. Mary Ewald as Timon. Photo credit: Seattle Shakespeare Company. 
Timon from Athens and into misanthropy. Timon's privilege could be repugnant; in spite of the spare staging, the production shows Timon and his friends indulging in the sort of excesses chronicled by the spoiled rich on Instagram. The play represents no particular time or place in costuming, while a simple circular stage, occasionally bisected by a light linen curtain, with a semicircle platform upstage, is all the set). Yet Ewald gives Timon sympathetic warmth that serves as foil to the frankly cynical dialogue of the parasites living off the character's generosity, and also explains the loyalty Timon's steward and servants show their master in his fall. Although Ewald demonstrates her command of spoken verse, so much of what's notable in her performance is in her physical acting, as I've suggested. Ewald embodies Timon's collapse: she shrinks on stage each time she is refused help, finally curling up in a fetal position outside the walls of Athens, alone in a way that disquietingly recalls how we both enter and leave this life alone.

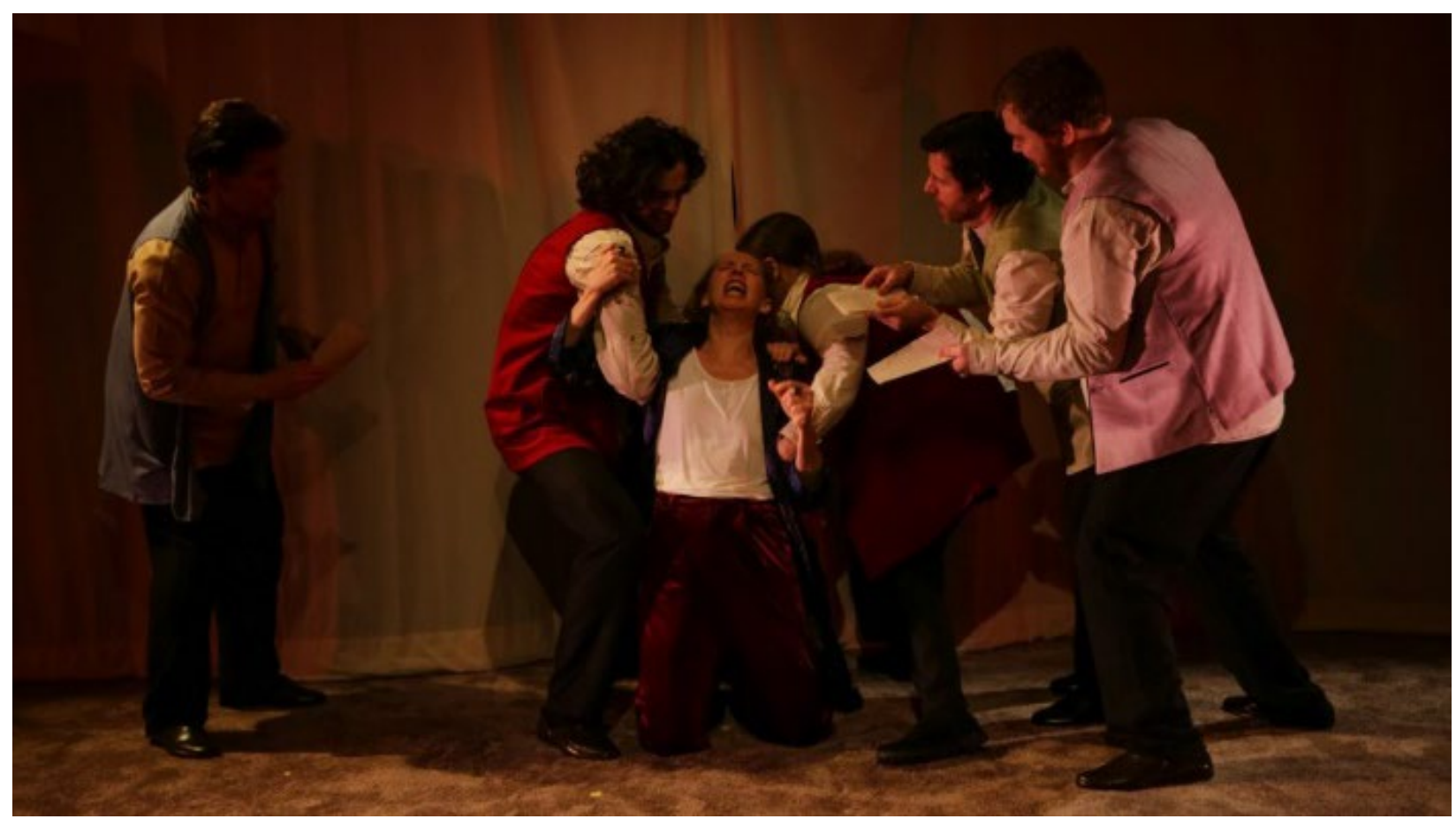

Figure 2. Mary Ewald as Timon collapses in distress. Photo credit: Seattle Shakespeare Company.

Ewald's physical performance finds its counterweight (philosophically, emotionally, and even physically) in Michael Winters's performance as Apemantus. Where Ewald begins tall and limber, reaching a climax of height as Timon blesses the meal of stones and water, and ends shrunken and crabbed in the forest, Winters remains a solid bulk, the fixed point to Timon's extremes of philanthropy and misanthropy. He lumbers into Timon's house, sits on a stool, produces a carrot, and philosophically snipes at those around him, a round figure contrasting with the leaping dancers partying to house music. In the latter part of the play, Apemantus 
visits Timon in the forest, finding Ewald scrambling in the dirt to produce a grimly wooden root, thereby out-cynicking the Cynic. Winters conveys a caring subtext to Apemantus's chastisement of Timon for not playing the social game (since Timon while wealthy was subject to the flatteries of parasites, Timon should now in poverty become a flattering parasite). Timon rejects these attentions, and Ewald develops the similarities in the text between Timon and Lear by giving Timon's misanthropy more wild madness than Apemantus's wry cynicism. Timon also rejects a loving visit from Flavius, his former steward (played by Peter Crook, who deserves praise for the empathy in his performance).

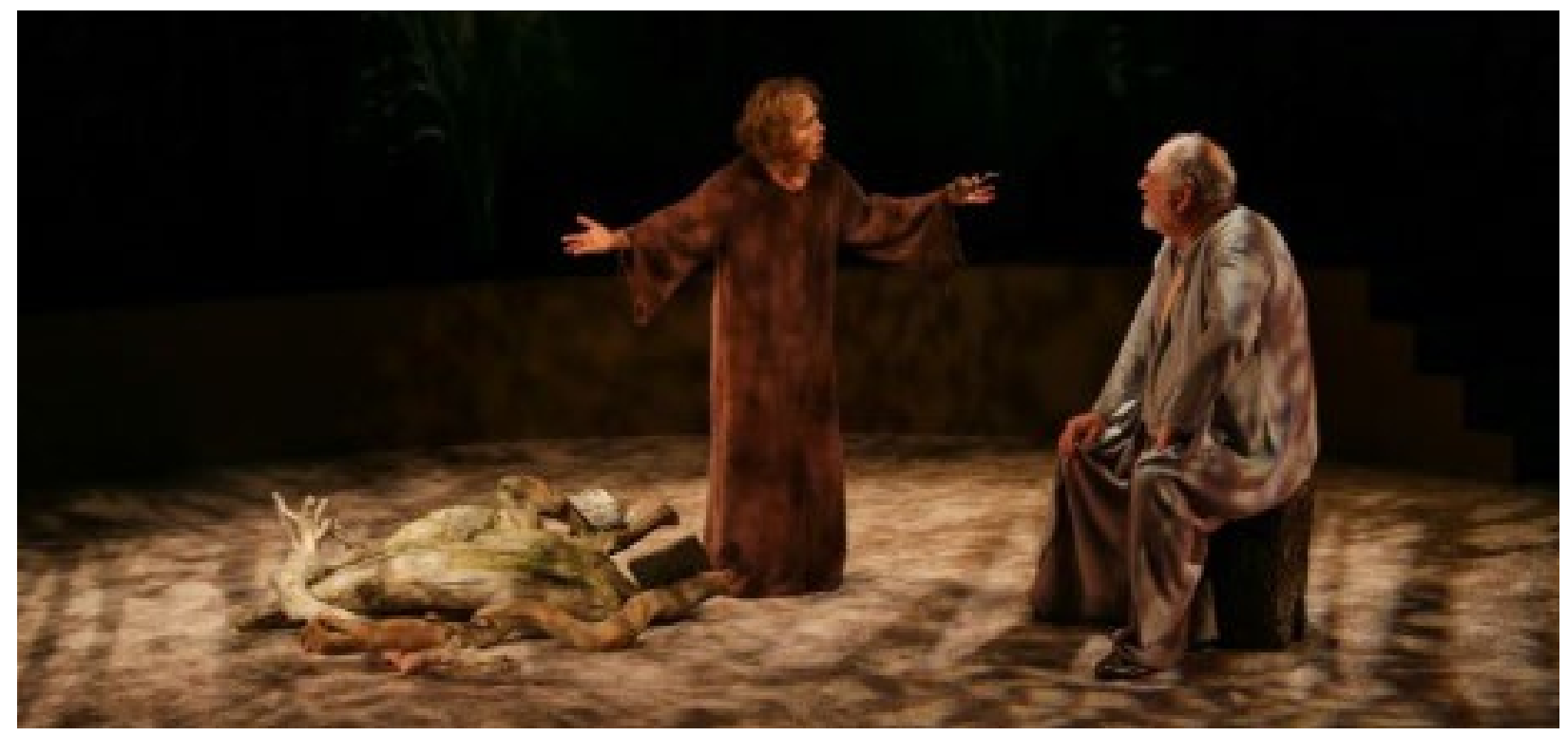

Figure 3. Mary Ewald as Timon with Michael Winters as Apemantus. Photo credit: Seattle Shakespeare Company.

This production follows Shakespeare's lead and has Timon die off-stage: the ultimate embrace of dramatic misanthropy, rejecting even the company of the audience in his last moments. The play ends with Alcibiades, the flamboyant and often mercurial bad boy of ancient Athenian politics (flatly played by Julie Briskman), returning from exile to seize control of the city, reading Timon's epitaph aloud to a group of city senators. The conclusion feels more like that of a Sophoclean tragedy than a Shakespearean, as the play tries to bind Timon's death to Alcibiades's return in ways that hint at something foundational and etiological, but shimmer away upon analysis. Neither play nor production persuades me that anything new will come of Timon's story or the change in Athenian power, particularly given the historical Alcibiades's near-traitorous reputation. His decrying Athens as "this [. . . lascivious town" rings hollow when one remembers the Alcibiades of Plato's Symposium: a drunken, spoiled, strongman onepercenter of the sort the Seattle production sets out to criticize. The conclusion and the dark, mournful tone are Shakespeare's doing, of course. 
I'm not sure the audience knew what to do with the play, and seeing it staged for the first time, I understood why it's not on the popular performance rota (I had neighbours in the theatre darkness who expressed their judgement through sleep on one side, and heavy sighs coupled with tight, audible rolling of a programme on the other). A.D. Nuttall calls Timon Shakespeare's strangest play, and strange it certainly is. Seattle Shakespeare should be commended for tackling it, if only as part of an effort to complete the canon. It's certainly Shakespeare's least familiar play. When the performance ended, the audience paused, unsure whether to applaud or not-partly perhaps because of the nature of the play, but I suspect mainly because they were uncertain whether the play were over or not (strange indeed to attend any performance of Shakespeare where the audience didn't know the text inside and out). When the houselights came up, Neil Young's "Heart of Gold" played as the audience filed out-a final cynical joke worthy of this play.

\section{References}

Nuttall, A.D. Shakespeare the Thinker. Yale University Press, 2007.

\section{Links}

Seattle Shakespeare Company. https://www.seattleshakespeare.org/ 


\section{Production Details}

\section{General}

Title

Timon of Athens

Year

2018

Theatre Company

Seattle Shakespeare Company

Theatre

Center Theatre, Seattle Center, Seattle, WA

Start Date

2018-01-09

End Date

2018-02-04

\section{Cast}

AlCIBIADES

FLAVIUS

Athenian, Lord, Messenger, Sempronius

TIMON

LORD, MERCHANT, SOldier, Stranger, VARro's

SERVANT, LUCIUS'S SERVANT

LORD, POET, SENATOR

Lucullus, Painter, Servant, Philotus

FLAMINIUS, LORD, LUCILIUS, SERVANT, VENTIDIUS

Lord, Messenger, Senator, Servant

Lord, Messenger, Prisoner, Servant

CAPHIS, JEWELLER, LORD, LUCIUS, VARRO'S SERVANT, SENATOR

LADY, SERVILIUS, TIMANDRA, SERVANT

APEMANTUS

\section{Creatives}

\author{
DIRECTOR \\ SET DESIGNER \\ Costume DesigneR \\ LIGHTING DESIGNER \\ SOUND DESIGNER \\ PROPERTIES DESIGNER \\ TECHNICAL DiRECTOR \\ STAGE MANAGER \\ ASSISTANT DIRECTOR \\ Assistant StAGE MANAGER \\ MASTER ELECTRICIAN
}

JULIE BRISKMAN

PETER CROOK

BRACE EVANS

MARY EWALD

JASON MARR

KEVIN MCKEON

Peter Dylan O'CONNOR

ARJUN PANDE

P. CULLEN RYAN

JASON SANFORD

KERRY SKALSKY

ALEXANDRA VERRIANO

MICHAEL WINTERS
JOHN KAZANJIAN

SHAWN KETCHUM JOHNSON

JOCELYNE FOWLER

LINDSAY SMITH

ROBERTSON WITMER

ROBIN MACARTNEY

BENJAMIN RADIN

MARIA GRAY

MARY EWALD

NinA TROTTO

LEVI Plumb 
SOUND ENGINEERS

WARDROBE MASTER
BRIAN MURPHY

KYLE THOMPSON

ANNA BOWEN 